\title{
INTEGRASI PENDIDIKAN SIAGA BENCANA DALAM \\ KURIKULUM MADRASAH IBTIDAIYAH
}

\author{
M. Sofyan al-Nashr \\ Institut Pesantren Mathali'ul Falah (IPMAFA) Pati \\ softyahn@gmail.com
}

\begin{abstract}
Abstrak
Tingkat kerentanan bencana di Indonesia sangat tinggi, hal ini tidak hanya karena faktor geografis di mana Indonesia berada di daerah rawan bencana, namun juga karena kualitas sumber daya manusia (SDM) Indonesia yang masih rendah dalam menghadapi ancaman bencana. Pengetahuan, sikap, dan perilaku manusia Indonesia bahkan semakin membuat ancaman bencana bertambah besar, misalnya bencana asap karena kebakaran hutan dan lahan yang banyak disebabkan ulah manusia yang sengaja membakar hutan untuk membuka lahan. Agar ancaman bencana tidak semakin besar, maka perlu menanamkan dan menumbuhkan karakter sadar, siaga, dan tanggap bencana kepada masyarakat. Salah satu caranya ialah melalui jalur pendidikan, yaitu mengintegrasikan pendidikan siaga bencana dalam pembelajaran. Langkah ini akan berdampak besar apabila dilakukan sejak dini, yakni di usia sekolah dasar (rentang 7-12 tahun). Madrasah sebagai salah satu lembaga pendidikan Islam bisa menjadi tempat yang tepat dalam menghasilkan generasi bangsa yang tanggap bencana. Karena hal ini sejalan dengan ajaran Islam di mana manusia merupakan khalifah di bumi yang bertanggung jawab terhadap kelangsungan hidup manusia dan alam.
\end{abstract}

Kata Kunci: pendidikan, siaga, bencana

\section{Abstract}

The level of vulnerability to disaster in Indonesia is very high, this is not just because factor geographically where Indonesia is prone to disasters, but also because of the quality of human resources (HR) Indonesia which is still low in the face of the threat of disaster. Knowledge, attitudes, and behaviors of human beings even more Indonesia makes the threat of disasters increases, for example smoke disaster due to forest fires and land that much of human behavior is caused intentionally burning forests to open land. So that the threat of disaster is not getting bigger, thus the need to inculcate and foster a character aware, alert, and disaster response to the community. One way is through the education, that is, integrate disaster preparedness education in learning. This step will have a major impact when done early, i.e. in primary school age (range 7-12 years old). Madrasah as one of Islamic educational institutions can be a great place in producing a generation of the nation's disaster response. Because this is in line with the teachings of Islam in which 
man was the Caliph on earth that are responsible for the survival of human beings and nature.

Keywords:education, standby, disaster

\section{A. Pendahuluan}

Indonesia merupakan negara dengan tingkat bencana alam yang tinggi dan bervariasi macamnya. Gempa bumi, tanah longsor, banjir, gunung meletus, kebakaran hutan serta beragam bencana alam lain. Kepulauan Indonesia terbentuk dari titik-titik pertemuan berbagai lempeng bumi. Di bagian barat, lempeng Eurasia bertumbukan langsung dengan lempeng Indo-Australia, dan di bagian timur adalah pertemuan tiga lempeng yaitu lempeng Filipina, Pasifik dan Australia. Letak geografis yang demikian ini, menjadikan negeri ini sarat dengan kejadian-kejadian bencana, seperti gempa bumi, tsunami, tanah longsor, serta gunung berapi. Selain itu, kerentanan Indonesia pun diyakini semakin meningkat dengan perubahan iklim global dan laju jumlah penduduk beserta pluralitas yang ada.

Kompleksitas kondisi demografi, sosial, dan ekonomi di Indonesia berkontribusi besar pada tingginya tingkat kerentanan masyarakat terhadap ancaman bencana, serta minimnya kapasitas masyarakat dalam menangani bencana menyebabkan risiko bencana di Indonesia menjadi lebih tinggi. ${ }^{1}$ Bencana yang paling mematikan pada awal abad XXI juga bermula dari Indonesia. Pada tanggal 26 Desember 2004, sebuah gempa bumi besar terjadi di dalam laut sebelah barat Pulau Sumatra di dekat Pulau Simeuleu. Gempa bumi ini memicu tsunami yang menewaskan lebih dari 225.000 jiwa di sebelas negara dan menimbulkan kehancuran hebat di banyak kawasan pesisir di negara-negara yang terkena. Di Indonesia sendiri gempa bumi dan tsunami mengakibatkan sekitar 165.708 korban jiwa dan nilai kerusakan yang ditimbulkannya mencapai lebih dari Rp 48 triliun.

Selain bencana-bencana berskala besar yang pernah tercatat dalam sejarah, Indonesia juga tidak lepas dari bencana alam yang terjadi hampir setiap tahun dan menimbulkan kerugian tidak sedikit. Banjir misalnya, hampir setiap tahun menimpa Jakarta dan sekitarnya, kota-kota di sepanjang daerah aliran sungai Bengawan Solo, daerah sekitar Semarang,

\footnotetext{
${ }^{1}$ Nurjannah, dkk, Manajemen Bencana, (Bandung: Alfabeta, 2011), hlm. 81.
} 
dan beberapa daerah lain di Indonesia. Demikian pula kekeringan yang semakin sering terjadi di beberapa daerah di Indonesia, selain mengancam produksi tanaman pangan juga kian mempermiskin penduduk yang mata pencahariannya tergantung pada pertanian, perkebunan dan peternakan. Bencana di musim kemarau lainnya yaitu kebakaran hutan dan lahan (kahutla) yang melanda beberapa propinsi di pulau Sumatera dan Kalimantan serta beberapa daerah lainnya. Selain menyebabkan ISPA hingga menimbulkan korban jiwa, bencana asap juga telah melumpuhkan bidang pendidikan dan ekonomi.

Tahun 2009, Badan Nasional Penanggulangan Bencana (BNPB) mencatat adanya 1.306 kejadian bencana dengan jumlah total korban meninggal sebanyak 624 jiwa meninggal dan hilang, 5.570 .928 orang yang menderita dan mengungsi akibat kejadian bencana tersebut, serta 77.975 rumah rusak. ${ }^{2}$ Itu artinya setiap hari terjadi lebih dari tiga kali bencana alam di tanah Indonesia. Tempat terjadinya tersebar di hampir seluruh wilayah nusantara, baik wilayah timur, tengah, maupun barat Indonesia.

Kebakaran lahan di Sumatera dan Kalimantan yang menyebabkan bencana asap hingga Malaysia dan Singapura menjadi contoh lain betapa tingginya tingkat kerentanan bencana di Indonesia. Musim kemarau yang panjang menyebabkan lahan gambut mudah terbakar. Ribuan hektar lahan yang terbakar mengakibatkan asap menyelimuti daerah tersebut hingga banyak jatuh korban jiwa karena penyakit ISPA. Ironisnya, bencana tersebut terjadi karena ulah manusia yang sengaja membuka lahan dengan cara membakar hutan.

Di Jawa Tengah, potensi bencana juga sangat besar, bukan hanya banjir dan tanah longsor, tetapi kondisi demografi dan sosial masingmasing daerah berpotensi terjadinya bencana alam yang berbeda-beda. Selain banjir di jalur pantura, letusan gunung berapi dan gempa bisa saja terjadi di Klaten, Magelang, atau Boyolali. Tanah longsor yang terjadi di Banjarnegara juga berpotensi melanda daerah perbukitan lain seperti Wonosobo, Purwokerto, Magelang, Kudus atau Temanggung. Daerah aliran Bengawan Solo juga menjadi daerah rawan bencana banjir yang bisa terjadi kapan saja.

Minimnya kapasitas masyarakat dalam menangani bencana menyebabkan risiko bahaya bencana di Jawa Tengah sangat tinggi.

${ }^{2}$ http://www.bnpb.go.id 
Masyarakat masih terlalu pasif dalam menghadapi ancaman bencana yang bisa datang kapan saja dan di mana saja. Sikap pasif inilah yang justru semakin berbahaya bagi keselamatan jiwa dan harta dari masyarakat itu sendiri. Agar resiko bencana bisa dikurangi maka diperlukan langkah nyata mitigasi (mengurangi resiko) bencana bagi masyarakat.

Pada tahun 2005 diselenggarakan Konferensi Dunia untuk Pengurangan Risiko Bencana (World Conference on Disaster Reduction) di Kobe, Jepang. Dari konferensi lintas-negara ini disusun dan disepakati kerangka kerja aksi bersama untuk pengurangan risiko bencana hingga tahun 2015. Kesepakatan tentang misi membangun ketahanan negara dan masyarakat terhadap bencana tersebut dikenal sebagai Platform Global untuk Pengurangan Risiko Bencana dengan Kerangka Kerja Hyogo 20052015 (Hyogo Framework for Action/HFA 2005-2015).

Kerangka aksi itu merekomendasikan 5 prioritas tindakan untuk dilakukan oleh suatu negara yakni: (1) Memastikan bahwa pengurangan risiko bencana (PRB) ditempatkan sebagai prioritas nasional dan lokal dengan dasar institusional yang kuat dalam pelaksanaannya; (2) Mengidentifikasi, mengevaluasi, dan memonitor risiko-risiko bencana dan meningkatkan pemanfaatan peringatan dini; (3) menggunakan pengetahuan, inovasi, dan pendidikan untuk membangun suatu budaya aman dan ketahanan pada semua tingkatan; (4) Mengurangi faktor-faktor risiko dasar; dan (5) Memperkuat kesiapsiagaan terhadap bencana dengan respon yang efektif pada semua tingkatan. Memperkuat kapasitaskapasitas pada tingkat komunitas untuk mengurangi risiko bencana pada tingkat lokal, di mana individu dan komunitas memobilisir sumberdaya lokal untuk upaya mengurangi kerentanan terhadap bahaya. ${ }^{3}$

Dengan potensi terjadinya bencana yang besar, maka dibutuhkan langkah antisipatif untuk mencegah dan serta menghadapi bencana. Pendidikan menjadi jalur yang sangat tepat untuk memberikan pemahaman terhadap bencana untuk kemudian menumbuhkan sikap tanggap akan bencana. Di tengah potensi bencana yang mengancam, maka pendidikan kebencanaan mutlak diperlukan. Sekolah sebagai lembaga pendidikan menjadi sarana yang tepat untuk memberikan pengetahuan, penanaman sikap hingga melahirkan perilaku yang tanggap bencana. Di

3 Dikutip dari Kerangka Kerja Sekolah Siaga Bencana yang disusun oleh Konsorsium Pendidikan Bencana di Indonesia tahun 2011. 
dalam kaitannya dengan upaya penanggulangan bencana di Indonesia, sekolah sebagai ruang publik memiliki peran nyata dalam membangun ketahanan masyarakat.

Tahun 2006, LIPI dan UNESCO mengadakan penelitian di tiga wilayah, yaitu Kabupaten Aceh Besar, Kota Bengkulu, dan Kota Padang. Penelitian ini bertujuan melihat tingkat kesiapsiagaan bencana di sekolah, rumah tangga, dan komunitas dengan 5 parameter (pengetahuan, kebijakan dan panduan, rencana tanggap darurat, sistem peringatan, dan mobilisasi sumber daya). Ditemukan bahwa tingkat kesiapsiagaan di sekolah lebih rendah dibanding masyarakat serta aparat. ${ }^{4}$ Ironis, mengingat sekolah sebagai lembaga pendidikan sepatutnya menjadi pioneer dalam mengantisipasi dan menghadapi potensi bencana.

Sekolah secara sadar dan terencana melakukan upaya mewujudkan suasana belajar dan proses pembelajaran agar peserta didik secara aktif mengembangkan potensi dirinya untuk memiliki kekuatan spiritual keagamaan, pengendalian diri, kepribadian, kecerdasan, akhlak mulia, serta keterampilan yang diperlukan dirinya, masyarakat, bangsa dan negara. Dalam hal ini sekolah tetap terpercaya sebagai wahana efektif untuk membangun budaya bangsa, termasuk membangun budaya kesiapsiagaan bencana warga negara; yakni secara khusus kepada peserta didik, pendidik, tenaga kependidikan, lingkungan sekitar dan para pemangku kepentingan lainnya, dan secara umum kepada masyarakat luas.

Madrasah sebagai sebuah institusi pendidikan -sekolah- yang khas dengan ajaran Islam sebagai dasarnya juga memiliki peran dan tanggung jawab yang sama besarnya dengan sekolah umum dalam upaya membangun kesiapsiagaan bencana. Baik Madrasah Ibtidaiyah (MI), Madrasah Tsanawiyah (MTs), maupun Madrasah Aliyah (MA) harus mampu menanamkan sikap dan perilaku siap siaga menghadapi bencana. Semakin anak mengerti dan memahami tentang kesiapsiagaan bencana, semakin besar pula keterampilan anak dalam menghadapi bencana.

Urgensi kesiapsiagaan bencana ini juga menjadi tanggung jawab madrasah sebagai lembaga pendidikan yang lahir dari masyarakat. Pendidikan siaga bencana akan lebih tepat ketika diajarkan sejak dini, utamanya saat masih di jenjang pendidikan dasar, yaitu sejak MI. Di sinilah

4 Deny Hidayati dkk, Kajian Kesiapsiagaan Masyarakat dalam Mengantisipasi Bencana Gempa dan Tsunami, (Jakarta: LIPI-UNESCO/ISDR, 2006), hlm. 5 
usia emas pembentukan karakter peserta didik yang akan berdampak pada karkater di masa depannya. Pada masa usia sekolah dasar kematangan perkembangan motorik ini pada umumnya dicapainya, karaena itu mereka sudah siap menerima pelajaran keterampilan. ${ }^{5}$ Maka pendidikan kebencanaan di jenjang MI akan sangat bermanfaat untuk menyiapkan generasi masa depan yang peduli bencana.

Berdasarkan latar belakang di atas, maka konsep pembelajaran yang mengintegrasikan antara kesiapsiagaan bencana dengan mata pelajaran di Madrasah Ibtidaiyah sangat diperlukan untuk akhirnya diterapkan dalam pembelajaran. Dengan demikian akan terlahir generasi muda yang tanggap menghadapi bencana. Setidaknya design itu mencakup perangkat pembelajaran secara komprehensif yang dapat menunjang tercapainya madrasah yang berwawasan bencana, meliputi proses sadar bencana, siaga bencana, hingga akhirnya tanggap bencana.

\section{B. Pembahasan}

\section{Madrasah dan Kesiapsiagaan Bencana}

Menurut Kamus Besar Bahasa Indonesia (KBBI), bencana merupakan sesuatu yang menyebabkan atau menimbulkan kesusahan, kerugian atau penderitaan. Sementara Undang-Undang No. 24 Tahun 2007 menyebutkan bahwa bencana adalah peristiwa atau rangkaian peristiwa yang mengancam dan mengganggu kehidupan dan penghidupan masyarakat yang disebabkan, baik oleh faktor alam dan atau faktor non alam maupun faktor manusia sehingga mengakibatkan timbulnya korban jiwa manusia, kerusakan lingkungan, kerugian harta benda, dan dampak psikologis. 6 Bencana merupakan pertemuan dari tiga unsur, yaitu ancaman bencana, kerentanan, dan kemampuan yang dipicu oleh suatu kejadian.

\footnotetext{
5 Syamsu Yusuf, Psikologi perkembangan Anak \& Remaja, (Bandung: PT Remaja Rosdakarya, 2009), hlm. 178

${ }^{6}$ Undang-undang Republik Indonesia Nomor 24 tahun 2007 tentang Penanggulangan Bencana
}

87 MAGISTRA - Volume 6 Nomor 2 Oktober 2015 
Bencana atau disaster is a consequence of complex processes which is starter from natural phenomenon such as wind and rain. ${ }^{7}$ Maksudnya ialah bencana merupakan konsekuensi komplek dari fenomena alam seperti angin dan hujan. Kondisi alam berpengaruh besar terhadap terjadinya bencana di suatu daerah. Pengertian tersebut lebih cenderung kepada bencana alam saja, yaitu sebuah bencana yang murni disebabkan oleh faktor alamiah.

Secara sederhana, bencana merupakan sebuah peristiwa yang berpotensi merusak dan menimbulkaan kerugian, baik yang disebabkan oleh alam, kejadian insidental, maupun kesalahan manusia. Sifatnya yang merusak dapat menyerang apa saja, di mana saja, kapan saja, dan siapa saja. Bencana dengan sifatnya yang merusak tentu akan mengakibatkan kerugian, baik dalam bentuk materiil maupun non materiil.

Undang-undang Nomor 24 Tahun 2007 tentang Penanggulangan Bencana (PB) dalam Bab I Pasal 1, mengelompokkan bencana ke dalam bencana alam, bencana non alam, dan bencana sosial. Bencana alam adalah bencana yang diakibatkan peristiwa atau serangkaian peristiwa yang disebabkan alam, antara lain gempa bumi, tsunami, gunung meletus, banjir, kekeringan, angin topan, dan tanah longsor. Bencana non alam adalah bencana yang disebabkan peristiwa atau rangkaian peristiwa nonalam yang antara lain berupa gagal teknologi, gagal modernisasi, epidemi, dan wabah penyakit. Bencana sosial adalah bencana yang mengakibatkan peristiwa atau serangkaian peristiwa yang disebabkan manusia, yang meliputi konflik sosial antar kelompok atau antar komunitas, dan teror. ${ }^{8}$

Mengingat Indonesia sangat berpotensi besar mengalami beragam ancaman bencana, gempa bumi, tanah longsor, banjir, gunung meletus, dan lain sebaagainya, maka dibutuhkan kesiapsiagaan dalam menghadapi bencana tersebut. Kesiapsiagaan dapat didefinisikan sebagai keadaan siap siaga. Berasal dari kata dasar siap siaga, yang berarti siap untuk digunakan atau untuk bertindak. Sementara definisi

7 Irwan Abdullah, Proceeding International Seminar Disaster, Theory, Research and Policy, the Graduate School of Gadjah Mada University, october 20 - 22, 2009, Yogyakarta: Kompas Gramedia, 2009, hlm. 11

8 Undang-undang Republik Indonesia Nomor 24 tahun 2007 tentang Penanggulangan Bencana 
kesiapsiagaan yang diberikan Undang-Undang Nomor 24 Tahun 2007 tentang Penanggulangan Bencana adalah serangkaian kegiatan yang dilakukan untuk mengantisipasi bencana melalui pengorganisasian serta melalui langkah yang tepat guna dan berdaya guna.

Badan internasional yang fokus pada strategi pengurangan resiko bencana, The United Nations International Strategy for Disaster Reduction (UNISDR) dalam buku Panduan tentang "Konstruksi Sekolah yang Lebih Aman" (Guidance Notes on Safer School Construction), menyatakan bahwa kesiapsiagaan adalah pengetahuan dan kapasitas yang dikembangkan oleh pemerintah, organisasi profesional penyelenggara tanggap darurat, dan pemulihan pasca bencana, masyarakat, dan individu untuk secara efektif mengantisipasi, merespon, dan pulih dari dampak peristiwa bahaya atau kondisi yang dapat terjadi dan akan terjadi. ${ }^{9}$

Kesiapsiagaan bencana dapat diartikan sebagai proses membentuk individu dari aspek pengetahuan, sikap, dan keterampilan dalam menghadapi ancaman bencana yang meliputi tindakan pencegahan dan penanggulangan bencana. Mental individu yang diharapkan yaitu sadar bencana (mengerti dan memahami tentang bencana), siaga bencana (sikap mencegah terjadinya ancaman bencana dan kesiapan menghadapi bencana), serta tanggap bencana (memiliki keterampilan dalam menghadapi dan mengatasi bencana).

Kesiapsiagaan ini menjadi sangat penting untuk mengurangi resiko banyaknya korban jiwa akibat bencana. Pengetahuan, sikap, dan keterampilan yang memadai terkait kesiapsiagaan bencana akan menjadi modal penting dalam upaya menyelamatkan jiwa dan harta benda sebanyak mungkin. Yang lebih penting tentu saja mencegah terjadinya bencana dengan menanamkan sikap dan perilaku sadar bencana.

Salah satu jalan menanamkan kesiapsiagaan bencana ialah melalui pendidikan. Pendidikan nasional yang bertujuan membentuk karakter peserta didik agar berakhlak mulia dan bertanggung jawab sangat tepat dijadikan media menyuburkan kesiapsiagaan bencana. Melihat ancaman bencana yang ada di hampir seluruh wilayah NKRI,

\footnotetext{
9 UNISDR, Termoinologi Pengurangan Risiko bencana Indonesia, (Bangkok: ADRRN, 2009), hlm. 26
} 
maka pendidikan siaga bencana menjadi sebuah kewajiban sekaligus kebutuhan.

Madrasah dalam peta dunia pendidikan di Indonesia bukanlah suatu lembaga yang indegenous (pribumi). Setidaknya hal ini dapat dilihat dari kata "madrasah" itu sendiri yang berasal dari bahasa Arab. Secara harfiah, kata ini berarti atau setara maknanya dengan school dalam bahasa Inggris yang diserap ke dalam bahasa Indonesia menjadi sekolah. ${ }^{10}$ Madrasah mengandung arti tempat atau wahana anak mengenyam proses pembelajaran. Maksudnya adalah, di madrasah inilah anak menjalani proses belajar secara terarah, terpimpin, dan terkendali.

Lembaga pendidikan madrasah mempunyai karakteristik yang menarik, madrasah didirikan untuk memadukan keunggulan pesantren dan sekolah, di samping untuk menghilangkan kelemahan di antara keduanya. ${ }^{11}$ Jadi bisa dikatakan madrasah adalah sekolah yang plus, perpaduan antara sekolah yang banyak pelajaran umumnya dengan pesantren yang menekankan pelajaran agamanya. Posisi ini menjadi strategis dari sisi budaya di mana karakter keislaman dapat dibangun secara moderat. Madrasah juga strategis dari sisi politis di mana eksistensinya dapat dijadikan sebagai parameter kekuatan Islam. Urgensi madrasah ini dalam tataran yang lebih makro dapat dilihat sebagai representasi wajah dan masa depan Islam Indonesia.

Sebagai lembaga pendidikan formal di Indonesia, madrasah menjadi salah satu pilar penting dalam melahirkan sumber daya manusia yang berkualitas dan berakhlak mulia. Dengan karakteristik madrasah yang unik dan menarik, tertanam optimisme tinggi untuk dapat meraih keberhasilan dalam upaya mewujudkan cita-cita dan tujuan pendidikan, yaitu berkembangnya potensi peserta didik agar menjadi manusia yang beriman dan bertakwa kepada Tuhan Yang Maha Esa, berakhlak mulia, sehat, berilmu, cakap, kreatif, mandiri, dan menjadi warga negara yang demokratis serta bertanggung jawab. ${ }^{12}$

10 A. Malik Fadjar, Madrasah dan Tantangan Modernitas, (Bandung: Mizan, 1999), Cet. 2, hlm. 18

11 Sutrisno, Pendidikan Islam Yang Menghidupkan, Cet II (Yogyakarta: Kota Kembang, 2008), hal 77

12 Sebagaimana tertuang dalam Undang-Undang RI Nomor 20 tahun 2003 tentang Sistem Pendidikan Nasional pasal 3, jika dibandingkan dengan sekolah 
Dalam upaya membangun kesiapsiagaan bencana, madrasah sangat tepat dijadikan tempat mengembangkan pendidikan siaga bencana. Madrasah tersebut dapat disebut dengan Madrasah Siaga Bencana (MSB) yang merupakan upaya membangun kesiapsiagaan madrasah terhadap bencana dalam rangka menggugah kesadaran seluruh unsur-unsur dalam lembaga pendidikan madrasah secara individu maupun kolektif, baik itu sebelum, saat maupun setelah bencana terjadi.

MSB meerupakan madrasah yang memiliki kemampuan mengelola resiko bencana di lingkungannya. Indikasi kemampuan tersebut diukur dengan dimilikinya perencanaan penanggulangan bencana (sebelum, saat dan sesudah), ketersediaan logistik, keamanan dan kenyamanan di lingkungan pendidikan, infrastruktur, serta sistem kedaruratan, yang didukung oleh adanya pengetahuan dan kemampuan kesiapsiagaan, prosedur tetap, dan sistem peringatan dini. Kemampuan tersebut juga dapat dinalar melalui adanya simulasi regular dengan kerja bersama berbagai pihak terkait yang dilembagakan dalam kebijakan lembaga pendidikan tersebut untuk mentransformasikan pengetahuan dan praktik penanggulangan bencana dan pengurangan risiko bencana kepada seluruh warga madrasah sebagai konstituen lembaga pendidikan.

MSB seperti halnya sekolah siaga bencana, terdapat beberapa tujuan utama, yaitu: ${ }^{13}$

1. Membangun budaya siaga dan budaya aman di sekolah dengan mengembangkan jejaring bersama para pemangku kepentingan di bidang penanganan bencana;

2. Meningkatkan kapasitas institusi sekolah dan individu dalam mewujudkan tempat belajar yang lebih aman bagi siswa, guru, anggota komunitas sekolah serta komunitas di sekeliling sekolah;

3. Menyebarluaskan dan mengembangkan pengetahuan kebencanaan ke masyarakat luas melalui jalur pendidikan sekolah.

Untuk mewujudkan madrasah yang siaga dan tanggap bencana, lengkap dengan perencanaan penanggulangan bencana, ketersediaan

\footnotetext{
umum jelas sekali madrasah seharusnya lebih mampu mencapai tujuan tersebut dengan kelebihan yang dimilikinya, yakni ajaran agama Islam. 13 http://p2mb.geografi.upi.edu/Sekolah_Siaga.html, dikutip tanggal 4 Maret 2015
} 
logistik, keamanan dan kenyamanan di lingkungan pendidikan, infrastruktur, serta sistem kedaruratan, yang didukung oleh adanya pengetahuan dan kemampuan kesiapsiagaan, prosedur tetap, dan sistem peringatan dini memang sangat sulit dilaksanakan. Hal itu mengingat problem klasik yang masih dialami kebanyakan madrasah yakni infrastruktur dan sarana pra sarana yang kurang menunjang pembelajaran. Ditambah lagi letak madrasah yang banyak berada di wilayah pedesaan, pedalaman, dan pinggiran kota daripada di perkotaan.

Akan tetapi, pembentukan karakter siaga bencana tidak harus menunggu fasilitas dan sarana yang lengkap baru pendidikan siaga bencana diterapkan. Yang paling penting dalam pendidikan siaga bencana ialah lahirnya generasi yang memiliki karakter siaga bencana, mengerti akan bencana dan bahayanya, bagaimana mencegahnya, serta apa yang harus dilakukan ketika terjadi bencana.

Pembentukan karakter tersebut tentu saja dapat dilakukan dalam pembelajaran di kelas, terutama pembelajaran di Madrasah Ibtidaiyah (MI) di mana anak usia MI (rentang 6-12 tahun) sedang mengalami masa terbaik dalam perkembangan otaknya. Pembentukan karakter siaga bencana dapat dilakukan dengan pembelajaran integratif, di mana pendidikan siaga bencana diintegrasikan dalam tiap proses pembelajaran.

\section{Integrasi Pendidikan Siaga Bencana dalam pembelajaran MI}

Menurut Fogarty, sebagaimana yang dikutip oleh Alexon dan Nana Syaodih Sukmadinata, bahwa model pembelajaran integrasi (terpadu) sebagai wujud pendekatan integratif bersifat kontinum yang berawal dari bentuk kurikulum tradisional di mana seluruh mata pelajaran merupakan bidang studi yang diajarkan terpisah-pisah sampai model yang berorientasi pada mata pelajaran yang sangat terpadu. ${ }^{14}$

Pembelajaran Integrasi sebagai suatu konsep merupakan pendekatan pembelajaran yang melibatkan beberapa mata pelajaran untuk memberikan pengalaman belajar yang bermakna bagi anak. Pembelajaran integrasi diyakini sebagai pendekatan yang berorientasi pada praktik pembelajaran yang sesuai dengan kebutuhan anak. Pembelajaran terpadu secara efektif akan membantu menciptakan kesempatan yang luas bagi

14 Alexon, Pengembangan model pembelajaran terpadu berbasis budaya untuk meningkatkan apresiasi siswa terhadap budaya lokal (Buletin Cakrawala, Juni 2010, th. XXIX, No. 2).

92 MAGISTRA - Volume 6 Nomor 2 Oktober 2015 
peserta didik untuk melihat dan membangun konsep-konsep yang saling berkaitan dari berbagai materi pelajaran.

Pembelajaran integrasi (terpadu) memiliki karakteristik ${ }^{15}$ :

1) Pembelajaran berpusat pada peserta didik

Berpusat pada peserta didik, karena dalam proses pembelajaranya memberikan keleluasaan pada peserta didik, baik secara individu maupun kelompok. Dengan begitu peserta didik dapat secara aktif mencari, menggali, dan menemukan konsep serta prinsip-prinsip dari suatu pengetahuan sesuai dengan taraf perkembangannya.

2) Menekankan pembentukan pemahaman dan kebermaknaan.

Pembelajaran integrasi (terpadu) mengkaji suatu fenomena dari berbagai macam aspek, sehingga akan berdampak pada kebermaknaan dari materi yang dipelajari peserta didik. Hal ini diharapkan akan berakibat pada kemampuan peserta didik untuk dapat menerapkan perolehan belajarnya pada pemecahan masalah-masalah yang nyata dalam kehidupannya.

3) Belajar melalui pengalaman langsung.

Pembelajaran integrasi (terpadu) diprogramkan untuk melibatkan peserta didik secara langsung pada konsep dan prinsip yang dipelajari dan memungkinkan peserta didik belajar dengan melakukan kegiatan secara langsung. Dalam hal ini guru bertindak sebagai fasilitator yang membimbing kearah tujuan yang hendak dicapai. Sedangkan peserta didik bertindak sebagai aktor pencari fakta dan informasi untuk mengembangkan pengetahuannya.

4) Lebih memperhatikan proses daripada hasil semata.

Pada Pembelajaran integrasi (terpadu) dikembangkan pendekatan discovery inqury (penemuan terbimbing) yang melibatkan peserta didik secara aktif dalam proses pembelajaran, yaitu mulai dari perencanaan, pelaksanaan sampai proses evaluasi. Pembelajarn ini dilaksanakan dengan melihat hasrat, minat dan kemampuan peserta didik, sehingga didik dapat termotivasi untuk terus belajar.

5) Sarat dengan muatan keterkaitan.

Pembelajaran integrasi (terpadu) memusatkan perhatian pada pengamatan dan pengkajian suatu gejala atau peristiwa dari beberapa

15 Sukayati, materi diklat; Pembelajaan tematik di SD merupakan terapan dari pembelajaran terpadu (Yogyakarta; PPPG, Agustus 2004), hlm 3-4 
mata pelajaran sekaligus, tidak dari sudut pandang yang terkotak-kotak. Sehingga memungkinkan peserta didik dapat memahami suatu fenomena pembelajaran dari segala sisi, yang pada akhirnya akan membuat peserta didik lebih arif dan bijak dalam menyikapi atau menghadapi kejadian yang ada.

Pembelajaran integratif di jenjang MI dengan karakteristiknya yang khas, sangat tepat untuk mewujudkan pendidikan siaga bencana. Integrasi pendidikan siaga bencana bukan diwujudkan dalam bentuk mata pelajaran sendiri yang diintegrasikan dengan mata pelajaran lain dengan tema yang saling berkaitan. Namun pendidikan siaga bencana diintegrasikan dalam tiap pembelajaran di semua mata pelajaran agar karakter siaga bencana peserta didik dapat berkembang dengan baik. Jadi dalam setiap mata pelajaran di kelas dijelaskan pula pelajaran yang dapat diambil dari kesiapsiagaan bencana.

Dalam proses belajar mengajar di MI, setidaknya terdapat tiga kurikulum formal yang dijalankan yaitu; pertama, kurikulum yang berhubungan dengan aspek teori dan terlukis berdasarkan apa yang tercantum dalam dokumen tertulis. Kedua, kurikulum yang dalam proses pembelajarannya dilaksanakan oleh guru di kelas atau dikenal dengan istilah implemented curriculum. Kurikulum ini merupakan pelaksanaan kegiatan belajar mengajar termasuk pelaksanaan penilaian hasil belajar siswa oleh guru. Ketiga, kurikulum yang tercermin dalam belajar yang dicapai siswa pada akhir satuan waktu pembelajaran, mulai dari satuan terkecil yaitu RPP sampai dengan satuan besar yaitu satu jenjang pendidikan atau lebih dikenal dengan performanced curriculum. ${ }^{16}$

Performance curriculum dalam pembelajaran integratif dengan kesiapsiagaan bencana mengharuskan kurikulum yang mencerminkan karakter siaga bencana. Di sinilah pendidikan siaga bencana diajarkan bersamaan dengan materi pelajaran sesuai jadwal yang disusun dengan tidak mengurangi materi pelajaran yang ada. Mengaitkan setiap materi dengan siaga bencana akan menumbuhkan sikap dan perilaku siaga bencana bagi anak-anak tanpa memberatkan mereka dengan materi khusus siaga bencana.

16 Pusat Kurikulum Depdiknas, Kajian Kebijakan Kurikulum Mata Pelajaran Matematika (Jakarta: Depdiknas, 2007), hlm. 5

94 MAGISTRA - Volume 6 Nomor 2 Oktober 2015 
Dalam implementasinya, integrasi pendidikan siaga bencana di jenjang MI membutuhkan perencanaan yang baik agar pelaksanaannya berjalan dengan lancar. Setiap guru dituntut menemukan kaitan materi pelajaran dengan bencana yang bisa dipahami peserta didik. Untuk itu materinya harus sederhana, konkrit, dan dekat dengan dunia anak. Hal ini dikarenakan usia sekolah dasar merupakan usia emas perkembangan anak di mana anak belajar dari sesuatu yang nyata dan dekat dengan kehidupan sehari-hari. Materi yang mereka dapatkan akan terekam dengan baik hingga akhirnya membentuk karakter siaga bencana yang akan tertanam kuat sampai mereka dewasa.

Itulah kenapa integrasi pendidikan siaga bencana lebih tepat diterapkan di jenjang MI daripada MTs atau MA. Pembentukan karakter siaga bencana harus dilakukan sejak dini ketika peserta didik masih berusia di bawah 12 tahun. Rentang usia yang tepat untuk menanamkan berbagai karakter baik bagi anak sebagai modal utama melahirkan generasi berkarakter di masa depan.

Menurut Piaget, usia sekolah dasar berada dalam tahap operasi konkret dalam berpikir (rentang usia 7-12 tahun). Piaget menemukan beberapa konsep dan prinsip tentang sifat-sifat perkembangan kognitif anak, diantaranya: ${ }^{17}$

- Anak adalah pembelajar yang aktif

Anak secara natural memiliki rasa ingin tahu tentang dunia mereka dan secara aktif berusaha mencari informasi untuk membantu pemahaman dan kesadarannya tentang realitas dunia yang mereka hadapi. Pada periode ini, mengenalkan, menanamkan, dan menumbuhkan karakter siaga bencana sangat tepat. Apalagi jika pendidikan siaga bencana dikemas dengan kemasan yang menarik serta memberikan pengalaman yang disukai anak seperti simulasi penanganan bencana.

- Anak mengorganisasi apa yang mereka pelajari dari pengalamannya Anak-anak tidak hanya mengumpulkan apa yang mereka pelajari dari fakta yang terpisah menjadi suatu kesatuan, tetapi juga membangun suatu pandangan menyeluruh tentang bagaimana dunia bergerak.

17 Desmita, Psikologi Perkembangan Peserta Didik, (Bandung: PT. Remaja Rosdakarya, 2011), hlm.98-101 
- Anak menyesuaikan diri dengan lingkungan melalui proses asimilasi dan akomodasi

Asimilasi terjadi ketika seorang anak memasukkan pengetahuan baru ke dalam pengetahuan yang sudah ada, yakni anak mengasimilasikan lingkungan baru ke dalam suatu skema yang telah mereka miliki. Sedangkan akomodasi terjadi ketika anak menyesuaikan diri pada informasi baru, yakni anak menyesuaikan skema mereka dengan pengetahuan dan lingkungan baru yang didapatnya.

- Proses equilibrasi menunjukkan adanya peningkatan ke arah bentukbentuk pemikiran yang lebih kompleks

Melalui proses asimilasi dan akomodasinya, sistem kognisi seseorang berkembang dari satu tahap ke tahap selanjutnya, sehingga kadangkadang mencapai keadaan equilibrium, yakni keadaan seimbang antara struktur kognisinya dan pengalamannya di lingkungan.

Berangkat dari teori konstruktivisme Piaget ini, sangat jelas dipaparkan bahwa anak-anak mampu membentuk kognisinya sendiri berdasarkan pengetahuan atau lingkungan yang baru saja dipelajari. Hingga akhirnya seorang anak mencapai keadaan equilibrium yang berupa kognisi dan sikap baru berdasarkan skema yang ia miliki dan pengetahuan serta pengalaman baru yang didapat.

Dengan demikian, mengintegrasikan pendidikan siaga bencana ke dalam pembelajaran MI akan mampu menanamkan kognisi tentang siaga bencana, menumbuhkan sikap sadar bencana, serta menghasilkan perilaku yang tanggap bencana. Karakter tersebut diharapkan mampu tumbuh dengan baik ketika masih usia anak-anak sehingga mereka akan tumbuh dan berkembang menjadi generasi yang tanggap bencana, yakni generasi yang peduli terhadap bencana, mencegah terjadinya bencana, dan tanggap menghadapi ancaman bencana.

\section{Menciptakan Budaya Siaga Bencana di MI}

Menumbuh-kembangkan karakter siaga bencana pada diri anak-anak usia MI memang bukan perkara mudah. Maka dari itu dibutuhkan dukungan dari seluruh elemen madrasah terutama budaya yang berlaku di lingkungan madrasah. Untuk menciptakan budaya 
siaga bencana di lingkungan MI, dibutuhkan kurikulum yang tepat, integratif, dan aplikatif. Kurikulum ini pada akhirnya harus diikuti oleh semua elemen lembaga, baik Kepala Madrasah, pendidik, tenaga kependidikan, maupun peserta didik. Kurikulum tersebut yaitu kurikulum yang terintegrasi dengan pendidikan siaga bencana. Dalam pengertian sempit, kurikulum merupakan seperangkat rencana dan pengaturan tentang isi dan bahan pelajaran serta cara yang digunakan sebagai pedoman penyelenggaraan kegiatan belajar mengajar di sekolah. Dalam arti luas, kurikulum merupakan segala kegiatan yang dirancang oleh lembaga pendidikan untuk disajikan kepada peseerta didik guna mencapai tujuan pendidikan.18

Menurut pandangan baru (modern) seperti yang dikemukakan oleh Romine (1954) merumuskan kurikulum sebagai berikut: "Curriculum is interpreted to mean all of the organized courses, activities, and experiences which pupils have under direction of the school, whether in the classroom or not". Maksudnya adalah bahwa tafsiran tentang kurikulum bersifat luas karena kurikulum bukan hanya mata pelajaran (courses), tetapi meliputi semua kegiatan dan pengalaman yang menjadi tanggung jawab sekolah. Pelaksanaannya tidak hanya dibatasi oleh dinding kelas saja tetapi juga di luar kelas sesuai dengan tujuan yang hendak dicapai. Tujuan pendidikannya bukan hanya menyampaikan mata pelajaran, melainkan pembentukan pribadi anak dan belajar cara hidup di masyarakat. ${ }^{19}$ Maka kurikulum siaga bencana harus dipandang dalam pengertian yang luas, yaitu semua kegiatan yang dirancang untuk mencapai tujuan pendidikan.

Maka setelah mengintegrasikan pendidikan siaga bencana dalam pembelajaran, pemberlakuan budaya siaga bencana di madrasah harus ditegakkan. Kewajiban menciptakan budaya siaga bencana di lingkungan madrasah bukan hanya tugas kepala madrasah namun seluruh elemen madrasah mulai dari pendidik, peserta didik, tenaga kependidikan, semua karyawan, dan stakeholder madrasah.

\footnotetext{
18 Muhaimin, Wacana Pengembangan Pendidikan Islam, (Surabaya: Pustaka Pelajar, 2004), cet. II, hlm. 182-183.

19 Oemar Hamalik, Dasar-dasar Pengembangan Kurikulum, (Bandung: PT. Remaja Rosdakarya, 2007), hlm. 3-5.
} 
Budaya siaga bencana dapat tercermin dari peraturan madrasah yang menunjang pengetahuan, sikap, dan perilaku siaga bencana. Hal itu antara lain menciptakan lingkungan belajar yang hijau, asri, bersih, dan rapi untuk mencegah banjir dan menambah serapan air tanah. Dapat pula dengan membiasakan diri membuang sampah di tempat sampah, baik ketika di madrasah maupun saat sudah di rumah. Atau dapat pula dengan media poster tentang pengetahuan dan penanggulangan berbagai bencana yang berpotensi terjadi di wilayah sekitar madrasah sesuai lokalitasnya, misalnya dengan poster tsunami bagi madrasah di dekat pantai, atau poster letusan gunning, tanah longsor, dan gempa bumi bagi madrasah yang berada di lereng gunung berapi.

Integrasi pendidikan siaga bencana dalam tiap kegiatan dan peraturan madrasah akan semakin mengasah aspek pengetahuan dan keterampilan siaga bencana bagi seluruh elemen madrasah, tak terkecuali peserta didik. Jika sudah demikian, maka pencegahan bencana akan dapat diwujudkan melalui madrasah, yang pada akhirnyaa akan meminimalisir korban harta dan jiwa dalam setiap bencana. Manusia tidak bisa memprediksi datangnya bencana, tetapi manusia dapat mencegah terjadinya bencana alam yang memakan banyak korban dengan pendidikan siaga bencana sejak dini.

\section{Simpulan}

Manusia memegang peran penting dalam terjadinya bencana, mereka bisa menjadi faktor utama pencegahan bencana di satu sisi, serta bisa menjadi faktor yang paling bertanggung jawab terhadapp terjadinya bencana. Tentunya manusia Indonesia selayaknya menjadi faktor utama dalam upaya pencegahan bencana dengan memberikan pendidikan siaga bencana sejak usia sekolah dasar sehingga akan lahir generasi sadar, siaga, dan tanggap bencana. Banyaknya bencana alam yang kerap terjadi di Indonesia, maka dipandang perlu dicanangkannya kurikulum pendidikan siaga bencana di satuan pendidikan formal sejak dini. Madrasah Ibtidaiyah salah satunya diharapkan dapat meingintegrasikan pendidikan siaga bemncana alam dalam kurikulum. Perlunya menananmkan dan menumbuhkan sikap sadar, siaga, dan tanggap bencana kepada masyarakat. 
Sejatinya, pendidikan siaga bencana diajarkan bersamaan dengan materi pelajaran yang ada, yakni mengaitkan setiap materi dengan siaga bencana yang akan menumbuhkan sikap dan perilaku siaga bencana bagi anak-anak. Materi yang disajikan harus bersifat sederhana, konkrit dan dekat dengan dunia anak. Mengintegrasikan pendidikan siaga bencana ke dalam pembelajaran MI akan mampu menanamkan kognisi tentang siaga bencana serta menghasilkan perilaku yang tanggap bencana.

Menciptakan budaya siaga bencana dibutuhkan dukungan seluruh elemen madrasah terutama budaya yang berlaku di sekolah. Integrasi pendidikan siaga bencana dalam setiap kegiatan dan peraturan madrasah akan semakin mengasah aspek pengetahuan dan keterampilan siaga bencana bagi sleuruh elemen madrasah. Apabila sudah menjadi budaya, maka pencegakan dapat diwujudkan dengan maksimal.

\section{DAFTAR PUSTAKA}

Abdullah, Irwan, Proceeding International Seminar Disaster, Theory, Research and Policy, the Graduate School of Gadjah Mada University, october 20-22, 2009, Yogyakarta: Kompas Gramedia, 2009

Alexon, Pengembangan Model Pembelajaran Terpadu Berbasis Budaya untuk Meningkatkan Apresiasi Siswa Terhadap Budaya Lokal, Buletin Cakrawala, 2010

Desmita, Psikologi Perkembangan Peserta Didik, Bandung: PT. Remaja Rosdakarya, 2011

99 MAGISTRA - Volume 6 Nomor 2 Oktober 2015 
Fadjar, A. Malik, Madrasah dan Tantangan Modernitas, Cet. 2, Bandung: Mizan, 1999

Hamalik, Oemar, Dasar-dasar Pengembangan Kurikulum, Bandung: PT. Remaja Rosdakarya, 2007

Hidayati, Deny, dkk, Kajian Kesiapsiagaan Masyarakat dalam Mengantisipasi Bencana Gempa dan Tsunami, Jakarta: LIPIUNESCO/ISDR, 2006

Konsorsium Pendidikan Bencana di Indonesia, Kerangka Kerja Sekolah Siaga Bencana, 2011

Muhaimin, Wacana Pengembangan Pendidikan Islam, cet. II, Surabaya: Pustaka Pelajar, 2004

Nurjannah, dkk, Manajemen Bencana, Bandung: Alfabeta, 2011

Pusat Kurikulum Depdiknas, Kajian Kebijakan Kurikulum Mata Pelajaran Matematika, Jakarta: Depdiknas, 2007

Sukayati, Pembelajaan tematik di SD merupakan terapan dari pembelajaran terpadu, Yogyakarta; PPPG, Agustus 2004

Sutrisno, Pendidikan Islam Yang Menghidupkan, Cet II, Yogyakarta: Kota Kembang, 2008

Undang-undang Republik Indonesia Nomor 24 tahun 2007 tentang Penanggulangan Bencana

Pendidikan Nasional

Nomor 20 tahun 2003 tentang Sistem

UNISDR, Termoinologi Pengurangan Risiko bencana Indonesia, Bangkok: ADRRN, 2009

http://p2mb.geografi.upi.edu/Sekolah Siaga.html diambil pada tanggal 20 April 2015

http://www.bnpb.go.id diunduh pada tanggal 23 April 2015 
Yusuf, Syamsul, Psikologi perkembangan Anak \& Remaja, Bandung: PT Remaja Rosdakarya, 2009 